University of Wollongong

Research Online

Faculty of Education - Papers (Archive)

Faculty of Arts, Social Sciences \& Humanities

2007

\title{
Relationships between objectively measured physical activity, movement competency and psychosocial outcomes in overweight and obese children
}

\author{
Dylan P. Cliff \\ University of Wollongong, dylanc@uow.edu.au \\ Anthony D. Okely \\ University of Wollongong, tokely@uow.edu.au \\ P Morgan \\ University of Newcastle, NSW, Australia \\ Julie R. Steele \\ University of Wollongong, jsteele@uow.edu.au \\ Rachel A. Jones \\ University of Wollongong, rachelj@uow.edu.au
}

Follow this and additional works at: https://ro.uow.edu.au/edupapers

Part of the Education Commons

\section{Recommended Citation}

Cliff, Dylan P.; Okely, Anthony D.; Morgan, P; Steele, Julie R.; and Jones, Rachel A.: Relationships between objectively measured physical activity, movement competency and psychosocial outcomes in overweight and obese children 2007, 67-67.

https://ro.uow.edu.au/edupapers/482

Research Online is the open access institutional repository for the University of Wollongong. For further information contact the UOW Library: research-pubs@uow.edu.au 
Relationships between objectively measured physical activity, movement competency and psychosocial outcomes in overweight and obese children

This study examined cross-sectional associations between physical activity and the psychosocial outcomes of selfesteem and health related quality of life (HRQoL), and fundamental movement skills (FMS) and psychosocial outcomes in overweight/obese children. Measures were collected from 165 overweight/obese children aged 5-9y (mean age $=8.2 \pm 1.1$; mean BMI-z $=2.81 \pm 0.71,41 \%$ boys) as part of the Hunter and Illawarra Kids Challenge Using Parent Support (HIKCUPS) RCT. Baseline data, split by gender, were used to explore relationships between activity/FMS variables and psychosocial outcomes for boys and girls separately. Measures included objectively measured physical activity (Actigraph 7164 accelerometer), video-assessed FMS (locomotor/object-control skills), selfesteem (athletic, social, scholastic, behavioural, physical appearance, global self-worth) and child- and parent-reported HRQoL. FMS were related to psychosocial outcomes though physical activity generally was not. When sub-domains of FMS were examined, locomotor skills were the stronger correlate of psychosocial outcomes in boys but object-control skills were the stronger correlate in girls. In girls, overall motor skills related to perceived physical appearance $(r=0.29$, $p=0.04)$ and object-control skills related to global self-worth $(r=0.42, p=0.002)$. Locomotor $(r=0.36, p=0.003)$ and object-control skills $(r=0.33, p=0.007)$ related to perceived athletic competence in boys. Cross-sectionally, movement competency appears to be related to psychosocial outcomes in overweight/obese children, though relationships differ by gender and movement skill sub-domain. Findings indicate the potential of targeting movement competency to promote improved psychosocial health in overweight and obese children, which warrants further experimental investigation. * HIKCUPS is funded by the NHMRC (354101). 